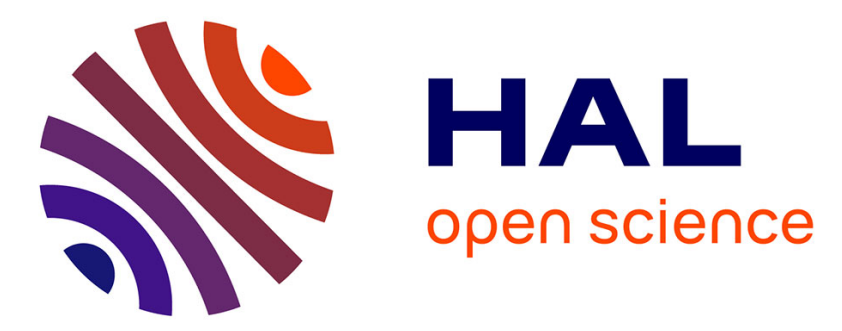

\title{
Microphytobenthos and an indicator of environmental quality status in intertidal flats: Case study of coastal ecosystem in Pertuis Charentais, France
}

Guoying Du, Hongmei Yan, Christine Dupuy

\section{- To cite this version:}

Guoying Du, Hongmei Yan, Christine Dupuy. Microphytobenthos and an indicator of environmental quality status in intertidal flats: Case study of coastal ecosystem in Pertuis Charentais, France. Estuarine, Coastal and Shelf Science, 2017, 10.1016/j.ecss.2017.06.031 . hal-01565701

HAL Id: hal-01565701

https://hal.science/hal-01565701

Submitted on 27 Nov 2017

HAL is a multi-disciplinary open access archive for the deposit and dissemination of scientific research documents, whether they are published or not. The documents may come from teaching and research institutions in France or abroad, or from public or private research centers.
L'archive ouverte pluridisciplinaire HAL, est destinée au dépôt et à la diffusion de documents scientifiques de niveau recherche, publiés ou non, émanant des établissements d'enseignement et de recherche français ou étrangers, des laboratoires publics ou privés. 


\section{Accepted Manuscript}

Microphytobenthos and an indicator of environmental quality status in intertidal flats:

Case study of coastal ecosystem in Pertuis Charentais, France

GuoYing Du, HongMei Yan, Christine Dupuy

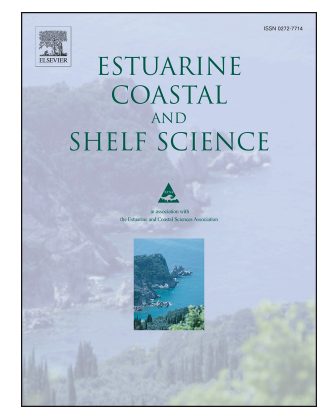

PII:

S0272-7714(17)30021-5

DOI:

10.1016/j.ecss.2017.06.031

Reference: YECSS 5521

To appear in: Estuarine, Coastal and Shelf Science

Received Date: 11 January 2017

Revised Date: 24 May 2017

Accepted Date: 25 June 2017

Please cite this article as: Du, G., Yan, H., Dupuy, C., Microphytobenthos and an indicator of environmental quality status in intertidal flats: Case study of coastal ecosystem in Pertuis Charentais, France, Estuarine, Coastal and Shelf Science (2017), doi: 10.1016/j.ecss.2017.06.031.

This is a PDF file of an unedited manuscript that has been accepted for publication. As a service to our customers we are providing this early version of the manuscript. The manuscript will undergo copyediting, typesetting, and review of the resulting proof before it is published in its final form. Please note that during the production process errors may be discovered which could affect the content, and all legal disclaimers that apply to the journal pertain. 


\section{ACCEPTED MANUSCRIPT}

Microphytobenthos and an indicator of environmental quality status in intertidal flats: case study of coastal ecosystem in Pertuis Charentais, France

GuoYing Du ${ }^{1^{*}}$, HongMei Yan ${ }^{1}$, Christine Dupuy ${ }^{2}$

${ }^{1}$ College of Marine Life Science, Ocean University of China, Qingdao 266003, China

${ }^{2}$ UMR 7266 'LIENSs', CNRS-University of La Rochelle, Institute for Coastal and Environmental Research (ILE),2 Rue Olympe de Gouges, 17000 La Rochelle, France

* Corresponding author at (Present address): E-mail address : duguo923@163.com; duguo923@ouc.edu.cn (GY. Du); Tel. +86 8203 1817; HP: +8615806530906 


\section{Abstract}

Microphytobenthos communities of different sediment types were investigated in intertidal flats of the coastal area around La Rochelle (Pertuis Charentais, France) in July, 2014 and January, 2015. Biotic variables of biomass, abundance and species composition of microphytobenthos were evaluated together with environmental variables, including irradiance, sediment temperature, grains size, pore water salinity, $\mathrm{pH}$, nutrients, organic matter, water content and heavy metal concentrations in the sediment. The relationships between biotic and environmental parameters showed that: (1) the microphytobenthos biomass and community structures showed significant differences among different sediment types; (2) variation in the microphytobenthos communities were significantly correlated with environmental variables, especially with the heavy metals, grain size, irradiance, pore water salinity, organic matter and concentration of $\mathrm{PO}_{4}{ }^{3+}$ and $\mathrm{Si}(\mathrm{OH})_{4} ;(3)$ the species number and richness were both significantly correlated with organic matter, and (4) the species Entomoneis corrugate, Navicula aitchelbee and Gyrosigma cf.limosum were positively correlated to heavy metals, and so were $\mathrm{N}$. phylleptosoma, Surirella brebissonii to $\mathrm{Si}(\mathrm{OH})_{4}$ and $\mathrm{NH}_{4}{ }^{+}$concentrations, and $\mathrm{G}$. acuminatum and $\mathrm{S}$. brebissonii to $\mathrm{PO}_{4}{ }^{3+}$ and $\mathrm{NH}_{4}{ }^{+}$. It is suggested that the spatial variation in biodiversity of microphytobenthos may reflect environmental quality status in coastal intertidal ecosystems.

Keywords: bioassessment; community; intertidal ecosystem; microphytobenthos; France, Pertuis Charentais

\section{Introduction}

Microphytobenthos (MPB) play an important role in the functioning of food webs as primary producers, influence sediment-water nutrient flux and contribute to sediment stabilization in various aquatic ecosystems, especially intertidal ecosystems (Round, 1979; Miller et al., 1996; Serôdio and Catarino, 2000; Underwood, 2010; Underwood and Kromkamp, 1999; Wainright et al., 2000). There have been many studies on community patterns and dynamics of marine MPB (Du et al., 2010; Lundkvist et al., 2007; Mitbavkar and Anil, 2002; Paterson, 1989; Paterson et al., 2000; Propp et al., 1980; Rysgaard et al., 1995; Underwood, 1994) and the species composition of MPB communities also shows a strong relationship with environmental factors, such as sediment grain size composition, salinity, nutrients ect (Agatz et al., 1999; Cibic et al., 2007; Facca and Sfriso, 2007; Méléder et al., 2007; Du et al., 2010, 2016). With short life cycles, standardized sampling protocols, availability of user-friendly taxonomic references, MPB have been suggested as indicators to evaluate environmental conditions and anthropogenic impacts in many aquatic ecosystems, especially in freshwater systems (Admiraal and Peletier, 1980; Blanchard et al., 2001; Brotas et al., 1995; Du et al., 2009; Guarini et al., 1998; Herlory et al., 2004; Kelly and Whitton, 1995; Sabbe, 1993).

The MPB (especially diatoms) have been widely used as a useful bioindicator of environmental quality status in freshwater systems (Chen et al., 2016; Kelly and Whitton, 1995; Lavoie et al. 2006; Solimini et al. 2006; Potapova and Charles, 2007; Stevenson et al., 2008 and 2010), and also were included in the EU Water Framework Directive (Directive 2000/60/EC). It demonstrated that diatom assemblage structure metrics more 
accurately assessed water quality and some species, such as Amphora pediculus and Cocconeis placentula were among the dominant species in low nutrients stream sites (Chen et al., 2016). The trophic diatom index (TDI) based on a suite of 86 taxa was highly correlated with aqueous $\mathrm{P}$ concentrations when tested on a dataset from 70 river sites free of significant organic pollution (Kelly and Whitton, 1995). And the Eastern Canadian Diatom Index (IDEC) successfully indicates the 'distance' from the non-impacted state under multiple stresses (Lavoie et al. 2006). Furthermore, Stevenson et al. $(2008,2010)$ developed robust indicators of the biological condition of diatom assemblages for streams of the western US. However, Kelly et al. (2009) also pointed out the uncertainty in ecological status assessment using diatoms owing to the spatial and temporal heterogeneity of the biological community in lakes and rivers.

Compared to the freshwater bodies, coast intertidal systems are subject to more fluctuating environmental factors (e.g. irradiance, temperature, nutrients and water content), which vary with the rise and recession of tides (Barranguet et al.,1998; Serodio and Catarino, 1999; de Brouwer et al., 2000; Christie et al., 2000; Thornton et al., 2002; Mitbavkar and Anil, 2006). Furthermore, due to complex environmental conditions in intertidal ecosystem which are directly affected by the open sea, it is more difficult to find the gradient distribution of specific factors, such as salinity, nutrient or pollutant, in coastal ecosystems than in smaller water systems as river or lake. Besides, interference by anthropogenic activities such as aquaculture and tourism, the relationship between MPB community and environmental factors is more complicated with regional characteristics, which makes the standardizing bioassessment by MPB more difficult in coastal system than in freshwater system. Therefore, there is much less information about MPB as a bioindicator in coastal ecosystems.

Nevertheless, as biotic factors, MPB not only could give an additional reference for the threshold values of which only depending on those chemical indices, but also due to their smart response, diatom assemblages could provide a more sensitive assessment of environmental quality than traditional water chemistry measurements (Katherine and Stephanie, 2005). The diatom assemblage can modify its structure to respond in a sensitive manner to the abrupt changes in multiple physical-chemical variables in a very short term (Cochero et al., 2015). However, for specific regions or stressors, a complete set of diatom species data and the coordinate environment data over a period of time is required, and the importance of spatial processes should be considered for marine coastal systems (Chen et al., 2016; Stevenson et al., 2008; Vilmi et al., 2016). Therefore, in terms of using marine MPB to assess the environmental quality status of coastal intertidal ecosystems, further studies should be carried out to enrich basic information for evaluating feasible criteria (Kelly et al., 2009; Méléder et al., 2007; Oppenheim, 1988; Smol and Stoermer, 2010).

In this study, the spatial-temporal variation of MPB and several abiotic factors were considered, in order to improve bioassessment using intertidal MPB. The main objectives of this study were: (1) to document the taxonomic composition and community structure of MPB communities in the different sediment types of intertidal flats; (2) to reveal the spatial variations in species composition of the MPB communities with 
contrasting environmental conditions, and (3) to determine the feasibility of community-based and species-specific bioassessment of environmental quality status using MPBs in coastal ecosystems.

\section{Materials and Methods}

\subsection{Study area and sampling}

This study was conducted in the coastal area around La Rochelle, along the French Atlantic coast in Pertuis Charentais area. Three sites were located on Re Island (Re), Aiguillon Bay (Ag) and Aytre Bay (Ay), respectively (Fig. 1). Site Re was part of an intertidal sand flat on the east-northern of Re Island, near an oyster farm. Site Ag was part of the mudflat of Aiguillon Bay $\left(47^{\circ} 00^{\prime} \mathrm{N}, 1^{\circ} 05^{\prime} \mathrm{W}\right)$, with a mussel farm located at a distance of $1 \mathrm{~km}$ off shore. Site Ay of Aytre Bay comprised sediments of mixed of mud and sand, and the seawater was reported to contain bacteria (and contamination by fecal coliforms) in the summer with the potential to cause human disease (C Dupuy, unpubl.).

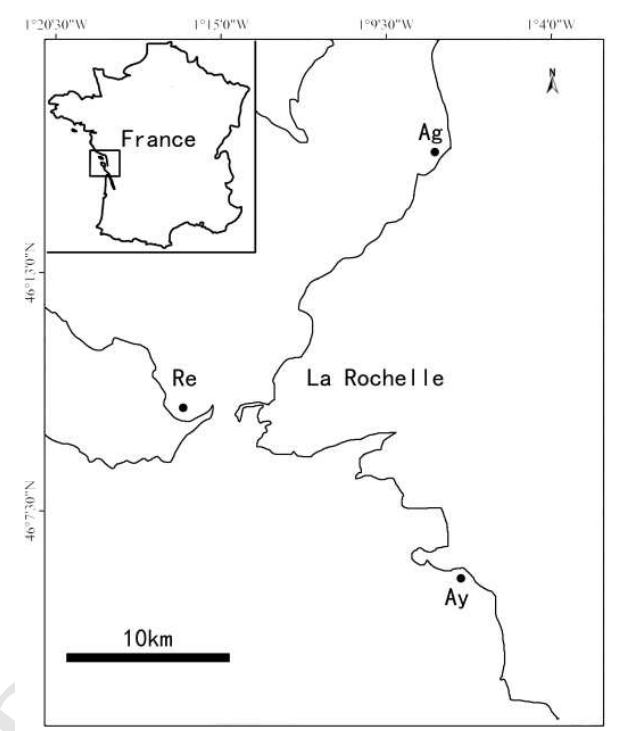

Fig.1. Sampling sites in the coast of La Rochelle, France, Re in Re Island,Ag in Aiguillon Bay;Ay in Aytre Bay.

Samples were collected during low tide on $12^{\text {th }}, 16^{\text {th }}$ and $17^{\text {th }}$ in July, 2014 and on $26^{\text {th }}, 28^{\text {th }}$ and $29^{\text {th }}$ of January 2015 for site Re, Ag and Ay, respectively. Sediment cores (12cm width) were collected on the basis of a systematic random sampling. The upper $0.5 \mathrm{~cm}$ or so sediment was immediately sectioned off. Three cores were mixed together as one sample (or replicate) and stored in a plastic box. Three samples were taken for each site or sub-site and kept in the dark at $4^{\circ} \mathrm{C}$ until processed in the laboratory for further analysis as cited below. The temperature of the upper $0.5 \mathrm{~cm}$ sediment and light irradiance on the sediment surface were monitored at 5 min intervals during the sampling process, using HOBO pro v2 sensor and WALZ ULM-50O light meter, respectively. The porewater of the upper $0.5 \mathrm{~cm}$ sediment was collected for each site or sub-site (Rhizon with crystal polystyrene syringes and Rhizon tube, Rhizosphere Research Products, NL-6706, Wageningen) (Seeberg-Elverfeldt et al. 2005). 


\subsection{Samples treatment and environmental factors measurements}

\subsubsection{Abiotic variables}

In the laboratory, subsamples were taken for measurement of physic-chemical variables. Nutrient concentrations (nitrates, nitrites, ammonium, phosphates and silicates) were determined with an autoanalyzer (Seal Analytical, GmbH Norderstedt, Germany) equipped with an XY-2 sampler according to Aminot and Kérouel (2007). Fifteen heavy metals ( $\mathrm{Ag}, \mathrm{Al}, \mathrm{As}, \mathrm{Cd}, \mathrm{Co}, \mathrm{Cr}, \mathrm{Cu}, \mathrm{Fe}, \mathrm{Hg}, \mathrm{Mn}, \mathrm{Ni}, \mathrm{Pb}, \mathrm{Se}, \mathrm{V}, \mathrm{Zn}$ ) in the sediments were analyzed by ICP-MS (X series 2 - Thermofisher Scientific). The pH was estimated by pH test paper (6-8), and the salinity was measured using a refractometer (ATAGO). Water content was determined as the percentage of water in relation to the fresh sediment weight by freeze-drying. Organic matter of sediment was estimated by weight loss of frozen-dried sediment at $450^{\circ} \mathrm{C}$ for $24 \mathrm{~h}$. Grain size of sediment was determined by a laser granulometer Mastersizer 2000 (Malvern Instruments Ltd, Worcs, U.K.).

\subsubsection{Microphytobenthic biomass, abundance and taxonomic composition}

Chlorophyll $a(\mathrm{chl} a)$ was extracted by $90 \%$ acetone from freeze-dried sediments in darkness overnight at $4^{\circ} \mathrm{C}$, measured using fluorimetery (Turner TD 700, Turner Designs, USA) after centrifugation (10 $\left.\mathrm{min}, 3500 \mathrm{~g}, 8^{\circ} \mathrm{C}\right)$, and corrected for phaeopigments according to the method of Lorenzen (1967). Chl $a$ concentration was expressed in $\mu \mathrm{g} \mathrm{chl} a \mathrm{~mL}^{-1}$ fresh sediment using volumetric mass as a proxy for MPB biomass. MPB was separated from sediment by the isopycnic separation technique using thesilica sol Ludox ${ }^{\circledR}$ (HS-40) (Ribeiro, 2010). Identification of benthic diatoms was performed to the species level by light microscopy and assisted by scanning electron microscopy (SEM), in accordance with Hustedt and Jensen (1985), Round et al. (1990), Tomas (1996), Witkowski et al. (2000), Ribeiro (2010). For the SEM, the diatom valves were cleaned in $30 \%(\mathrm{v} / \mathrm{v}) \mathrm{H}_{2} \mathrm{O}_{2}$ at $90{ }^{\circ} \mathrm{C}$ for 1 to 3 hours and washed 5 times with distilled water (gentle centrifugation 2500 g, 10 min; Taylor et al., 2005). Diatoms abundance was estmated under light microscope (400 $\times$ and $1000 \times$ magnification, Zeiss Axioskop). The diatom valves were counted for 400 valves of diatoms/each sample of at least 50 random fields, up to 100 random fields. Abundance (cell density) of each species was calculated by multiplying the number of cells by the dilution factor, while adjusting the value to $3 \mathrm{ml}$ volume of subsample. The relative abundance of a species was the proportion of the particular species in the total abundance of one sample.

\subsection{Data analysis}

Differences in abundance, biomass (chlorophyll a concentration) and community indices of the sampling months and sites were tested through univariate analysis of variance followed by Fisher's least significant difference (LSD) tests. The correlations between biomass, abundance, species and environmental factors were determined by multivariate correlation analyses. These analyses were performed using SPSS 21.0. Ordination analysis was carried out using CANOCO for Windows 5.0 to assess the relationship of species composition with environmental factors. Analysis included a total of 30 samples (all samples for two seasons), 61 species, and 28 environmental factors. Species data were log $(1 * Y+1)$ transformed. The nonmetric multidimensional scaling 
(nMDS) analysis was used to classify the samples based on the species composition. Detrended correspondence analyses (DCA) (detrended by segments) was used to determine gradient lengths, so as to assess whether a linear or unimodal multivariate method should be used. Because the longest length was3.1 (3 $<X<4$, both methods could be used, Ter Braak and Šmilauer, 2002), a unimodal ordination method was chosen. Principal component analysis (PCA) was used to explore the major variation patterns in the data set (with centering of the species data). The ordination scores in the PCA diagram were focused on inter-species correlation', and the species scores were post-transformed. The PCA bioplot based on the species composition of every sample was used to illustrate the spatial distribution of MPB. Based on the variance inflation factors (VIF) and Monte Substitute test, top 11 environmental factors were used for further analysis. Finally, detrended canonical correspondence analyses (DCCA) and an unrestricted Monte Carlo permutation test (MCP-test) were applied to test for statistical significance between environmental factors and their effects on species composition variability.

\section{Results}

\subsection{Environmental factors}

Environmental factors for the sampling sites in summer and winter are summarized in Table 1. Temperature, irradiance and salinity had notable seasonal difference for all sampling sites between summer and winter. Less difference of temperature and irradiance existed among three sampling stations except for site Ay when it was raining during the sampling in winter, e.g. the salinity and irradiance were extremely low as 10 and $97.1 \mu \mathrm{mol} \mathrm{m} \mathrm{m}^{-1}$ respectively, and temperature was $11^{\circ} \mathrm{C}$. In addition, site Ay also had larger difference in grain size $\left(D_{50},<63 \mu \mathrm{m} \%\right)$, organic matter $(\mathrm{OM})$, water content $(\mathrm{WC}, \%)$ and nutrients of $\mathrm{NO}_{3}{ }^{-}$and $\mathrm{NO}_{2}{ }^{-}$ between the two seasons than the other two sites. Generally, the sediment characteristics of the three sites were clearly characterized by the diameter medium $D_{50}$ and the percentage of grain size $<63 \mu \mathrm{m}$ (Table 1). Details of sediment composition were presented by the grain size proportions of mud $(<63 \mu \mathrm{m})$, very fine sand

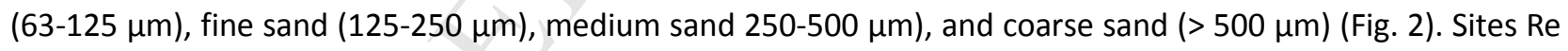
and $\mathrm{Ag}$ had little difference in $\mathrm{OM}$ and $\mathrm{WC}$ between summer and winter. The $\mathrm{pH}$ value was relatively stable $(P>$ 0.05) except slightly higher at stations Ag and Ay in winter. Dissolved inorganic nutrient concentrations in pore water oscillated dramatically across sampling sites and different nutrients. In details, the species of nitrogen $\left(\mathrm{NO}_{2}{ }^{-}\right.$and $\left.\mathrm{NO}_{3}{ }^{-}\right)$increased during winter, especially $\mathrm{NO}_{3}{ }^{-}$increased more than 10 times. In contrast, the concentration of $\mathrm{PO}_{4}{ }^{3-}$ decreased in winter, and the $\mathrm{NH}_{4}{ }^{+}$and $\mathrm{Si}(\mathrm{OH})_{4}$ values were slightly higher at site Re but were lower at site $\mathrm{Ag}$ and $\mathrm{Ay}$ in winter than in summer. The highest $\mathrm{NH}_{4}{ }^{+}$and $\mathrm{Si}(\mathrm{OH})_{4}$ value was observed at site $\mathrm{Ag}$ in summer, and the lowest at station Re in summer. The extremely highest $\mathrm{NO}_{3}{ }^{-}$value (average $395.9 \mu \mathrm{mol}$ $\mathrm{L}^{-1}$ ) was measured at site Ay in winter, but ranged from 3.7 to 5.2 without significant difference among the three sites in summer $(P>0.05)$, and varied from 41.4 to 73.3 (no significant difference) between site Re and Ag in winter $(P>0.05)$. 

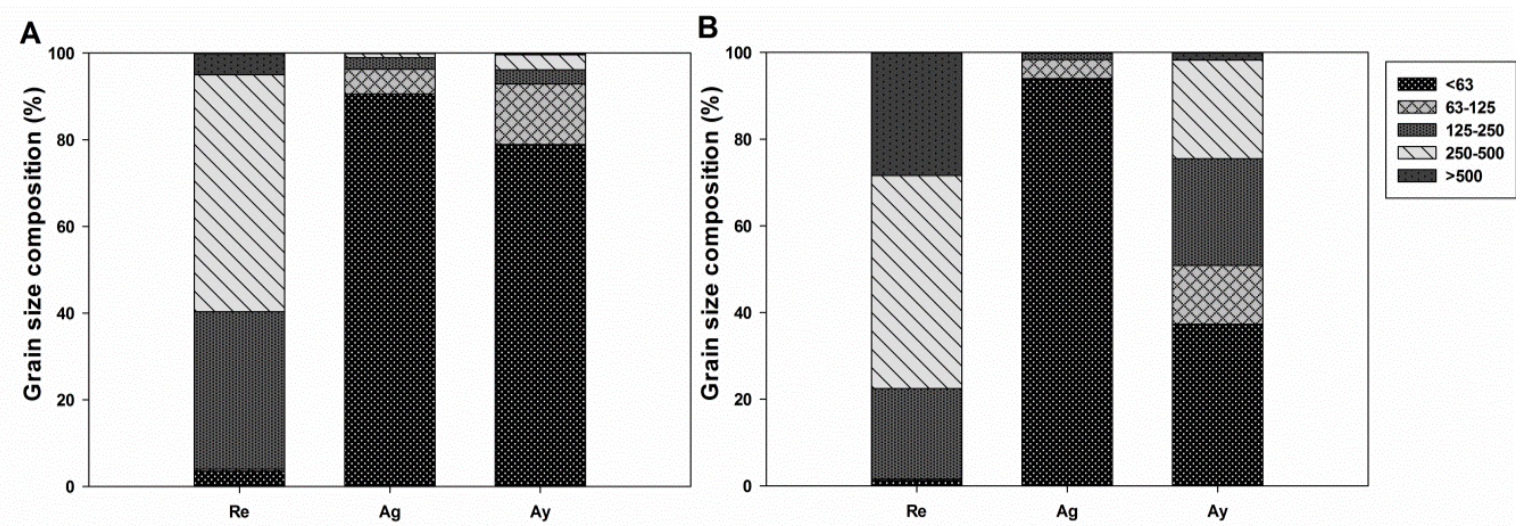

Fig.2. Grain size distribution in the studied sites. Grain size fractions expressed in percentage and consisted of mud $(<63 \mu \mathrm{m})$, very fine sand $(63-125 \mu \mathrm{m})$, fine sand $(125-250 \mu \mathrm{m})$, medium sand $(250-500 \mu \mathrm{m})$, and coarse sand $(>500 \mu \mathrm{m})$; A: summer, B: winter.

Strongly multicollinearity was found among the variability of 15 heavy metals ions in sediments, indicated by high variance inflation factors (VIF > 20). Therefore, $\mathrm{Zn}^{2+}$ concentration was used as a proxy to represent the 15 measured heavy metals based on its minimum $p$ value of the $F$-statistic (Table 1 ). Statistical analyses showed significant differences $(P<0.05)$ in these environmental variables among/between three sampling sites. The general trends of heavy metals concentration in three sites was $\mathrm{Ag}>\mathrm{Ay}>\mathrm{Re}$ whether in summer or winter.

\subsection{Biomass, abundance and taxonomic composition of MPB}

MPB biomass indicated by Chlorophyll $a$ concentrations of all samples varied from 5.96 to $42.21 \mathrm{\mu g} \mathrm{mL}^{-1}$ fresh sediment in summer and from 5.39 to $51.22 \mu \mathrm{g} \mathrm{mL}^{-1}$ in winter (Table 2). Among three sampling stations, the highest biomass and chl a/ pheo-pigments ratio were found at site Re with sandy sediments, but the lowest in both seasons at site Ag with muddy sediment (Table 2). Comparing to other two sites, the biomass $(p)$ and chl $a /$ pheo-pigments ratio varied significantly $(p<0.05)$ at site Ay with mixed sandy and muddy sediment between summer and winter. Although the highest species number was founded at site $\mathrm{Ag}$, the Shannon diversity index $\left(H^{\prime}\right)$ indicated relatively higher species diversity at site $\mathrm{Ay}$, slightly lower at site $\mathrm{Ag}$, and lowest at site Re both in summer and winter (Table 2). The cell abundance of MPB showed higher values in winter for all sites, and the difference between seasons was significant in sandy sediment $(P<0.05)$, and extremely significant in mixed sandy and muddy sediment at site Ay $(P<0.01)$, but not in muddy sediment at site Ag. The correlation analysis also showed low coefficient as 0.567 but significantly positive relationship between biomass and abundance $(P$ $\leq$ 0.01). There were no significant difference for Shannon index and Pielou Evenness Index for all sites and seasons. Significant difference of species richness was found between the two seasons at site Ay.

In summer, a total of 111 species of 46 genera were recorded. Among them, 35 species of 18 genera presented in the sand sediment of site Re with highest abundance of $10.7 \times 10^{5}$ cells mL ${ }^{-1}$ fresh sediment; 70 species of 35 genera were observed in mud sediment of site Ag with lower abundance of $4.03 \times 10^{5}$ cells mL $^{-1}$, and 58 species of 33 genera were identified in sand and mud mixing sediment of site Ay, with lowest abundance of $0.928 \times$ $10^{5}$ cells $\mathrm{mL}^{-1}$. In winter, only 75 species of 30 genera were observed in three sites, among them, 30 species of 
14 genera, 60 species of 25 genera and 28 species of 13 genera presented in site Re, site $\mathrm{Ag}$ and site $\mathrm{Ay}$, respectively with $25.4 \times 10^{5}$ cells $\mathrm{mL}^{-1}, 4.30 \times 10^{5}$ cells $\mathrm{mL}^{-1}$ and $6.30 \times 10^{5}$ cells $\mathrm{mL}^{-1}$.

The MPB species with relative abundance $>5 \%$ observed in summer and winter are illustrated respectively for each sample (Figure 3A and B). In summer, the most dominant species Navicula consentanea was distributed over all different types of sampled sediment, reaching highest relative abundance as $34.5 \%, 25.7 \%$ and $15.9 \%$ of the diatom assemblage in site $\mathrm{Re}, \mathrm{Ag}$ and $\mathrm{Ay}$, respectively. In addition, Amphora hassiaca (1.8-7.3\%), Cocconeis hauniensis (1.3-8.1\%), N. germanopolnica (9.5-14 \%), N. perminuta (8.5-20.1\%), Fallacia scaldensis (1.0-10\%), were abundant in the sand sediment of site Re; N. gregaria (10.6-33.5\%), N. phylleptosoma (8.4-25.8\%), Gyrosigma acuminatum (0.0-12.4\%), N. dilucida (0.8-7.8\%) occurred more frequently in mud sediment of site Ag; and Planothidium aff. engelbrechtii (10.3-13\%), N. gregaria (26.1-30.2 \%), P. deperditum (3.5-6.7 \%) thrived in the sand-mud mix of sediment at site Ay. In winter, dominant species varied little in site Re, where $N$. consentanea was still the most abundant (24.0-34.3\%), F. scaldensis abundance was similar to that of summer (3.5-11.8\%), but more N. germanopolnica (11.3-32.7\%), N. gregaria sippe (5.5-10.8\%) and $N$. perminuta (5.5-25.1\%) were present. In site $\mathrm{Ag}$, except $N$. dilucida (0.8-7.8\%) was similar to that of summer, Gyrosigma fasciola became the most abundant in some samples (8.0-69.5\%), and Skeletonema costatum appeared frequently (0-24.4\%). In site Ay, the $N$. consentanea kept a consistent relative abundance with that of summer (3.5-12.2\%), P. engelbrechtii (7.75-16.04 \%) varied slightly, and N. dilucida (15.3-39.5\%) and $N$. perminuta (13.3-16\%) became more abundant.

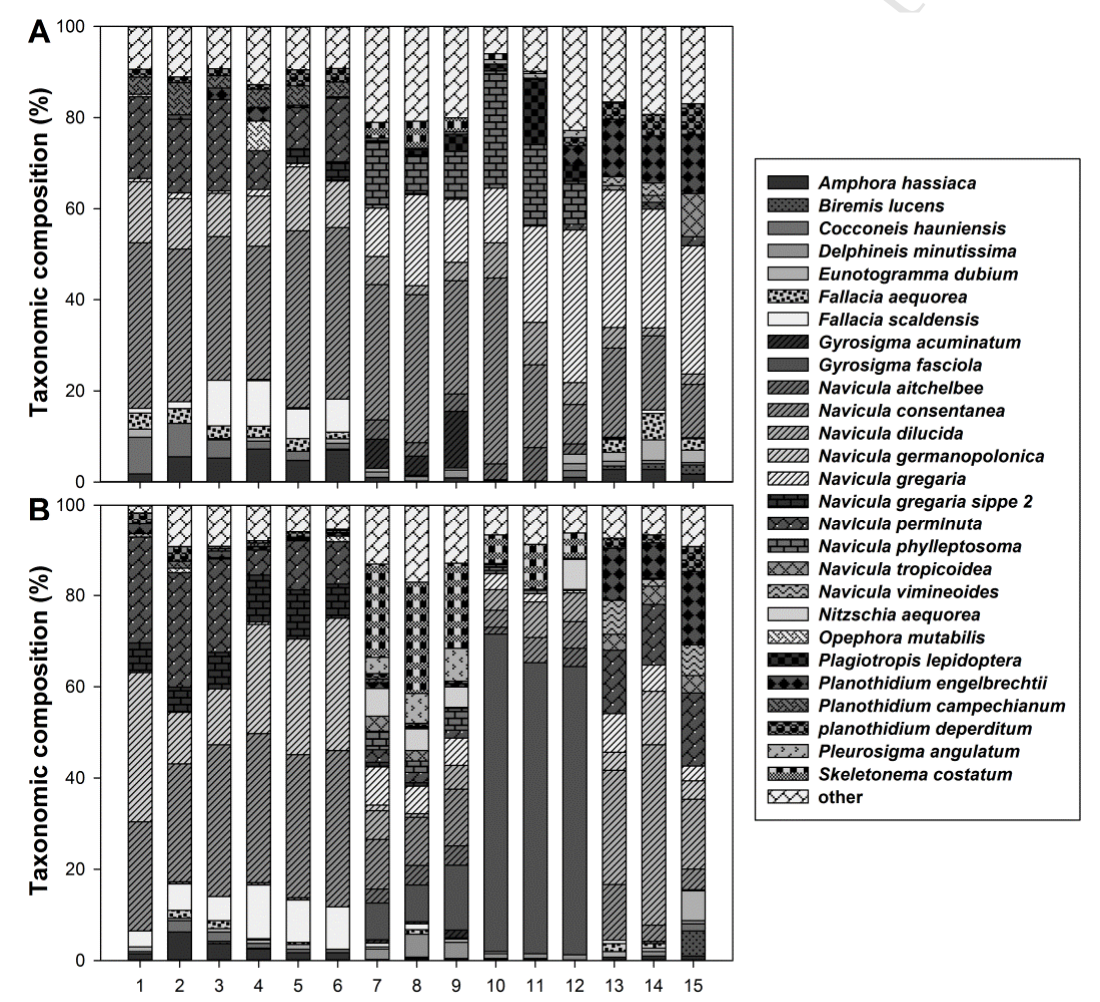

Fig.3 Taxonomic composition of microphytobenthic communities of individual samples collected from site $\operatorname{Re}(1-6), \mathrm{Ag}(7-12)$ and Ay (13-15), A: summer; B: winter. (The species with relative abundance above $5 \%$ are presented, with the remaining species 
grouped as 'others'. The relative abundance is presented as the percentage of the total cells counted).

NMDS analysis on species composition pooled for all samples clearly separated the assemblages of the three individual sampling sites (Fig. 4). The summer and winter groups of site Ay were easily distinguished from each other, and the seasonal groups of site Ag also could be separated. However, in site Re, the summer and winter assemblages were overlapping due to their closer similarity. Different structural community types could be recognized according to representative species: (1) those featured by Navicula germanopolnica, N. perminuta and Fallacia scaldensis (at site Re with sand sediment); (2) those by N. aitchelbee, Skelethonema costatum and Entomoneis corrugate (at site Ag with mud sediment), and (3) those by Planothidium septentrionalis, P.aff. engelbrechtii (site Ay with sand mixing mud sediment) (Fig.3 and Fig.4).

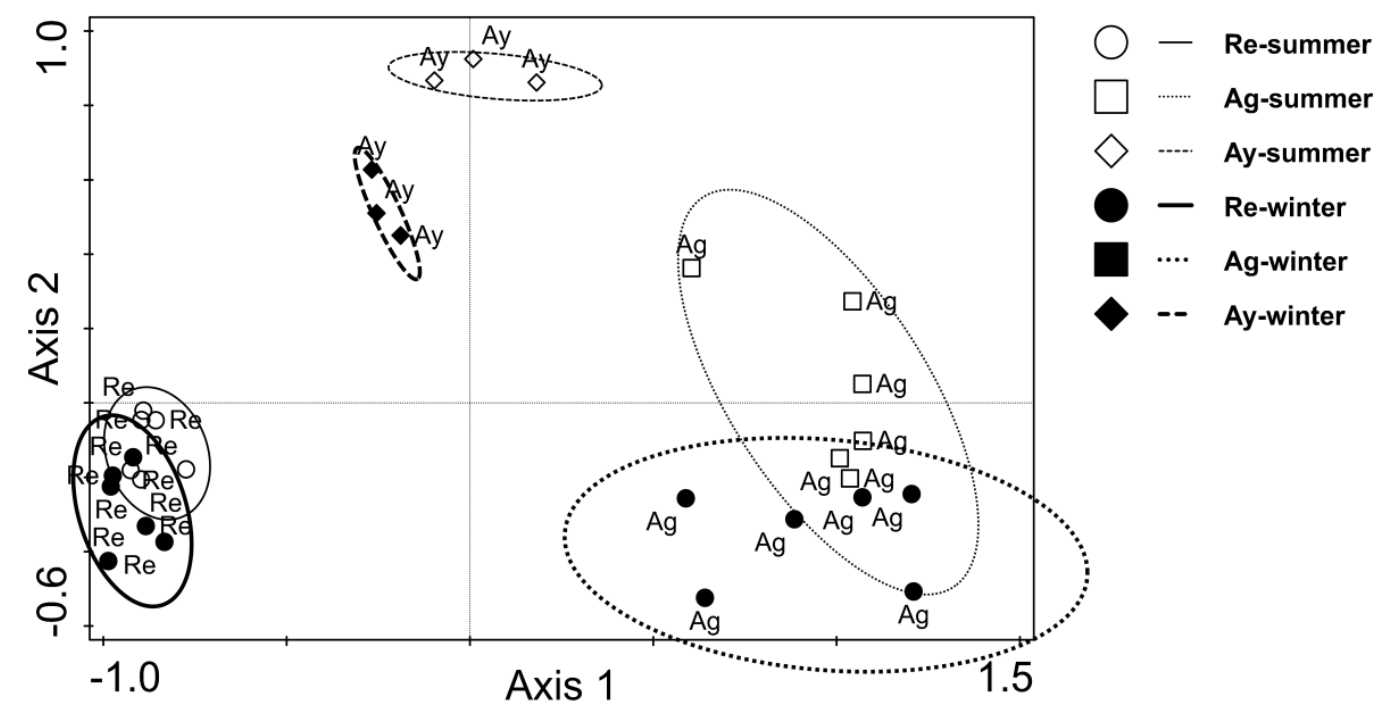

Fig.4. Classification of samples based on species composition by nonmetric multidimensional scaling (nMDS) in CANOCO 5.0.

\subsection{Relationship between MPB communities and environmental conditions}

Multivariate correlation analysis revealed that MPB biomass was significant positively correlated with D50 $(r=0.803, P<0.01)$, and significantly $(P<0.01)$ negatively related to $<63 \mu \mathrm{m}$ (mud, $r=0.845)$, and heavy metals (proxy of $\left[\mathrm{Zn}^{2+}\right]$ ), water content, organic matter, $\mathrm{Si}(\mathrm{OH})_{4}, \mathrm{NH}_{4}^{+}(\mathrm{r}=-0.907 ;-0.903,-0.753,-0.615,-0.514$, respectively). Other environmental factors, such as nutrients of $\mathrm{NO}_{n}^{-}, \mathrm{PO}_{4}{ }^{3+}$, sediment temperature, salinity, irradiance and $\mathrm{pH}$ had no significant $(P>0.05)$ relationship with MPB biomass. The DCCA revealed the relationships of species composition with environmental conditions for all samples. It was shown that $56 \%$ of the total variance of species composition could be represented by the first two axes (Fig. 5). 


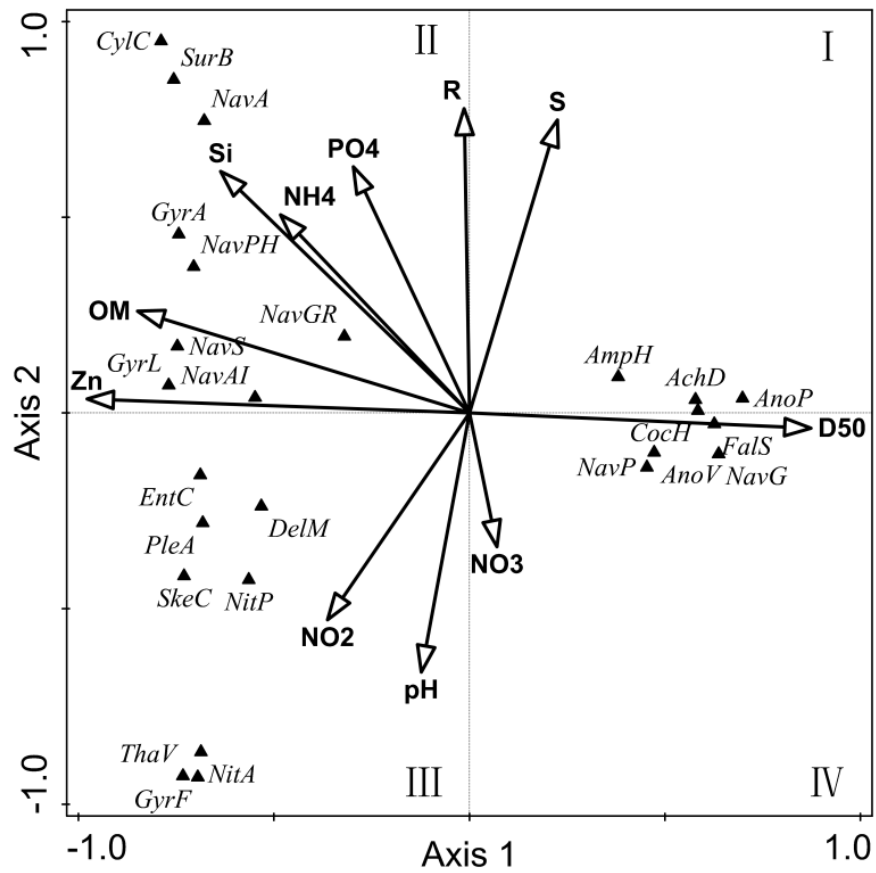

Fig.5. Detrended canonical correspondence analysis (DCCA) based on square-root transform of speciesabundance. The solid arrowheads and italic labels indicate the species: AchD: Achnantheiopsis delicatula; AmpH: Amphora hassiaca; AnoP: Anorthoneis pulex; AnoV: Anorthoneis vortex; $\mathrm{CocH}$ : Cocconeis hauniensis; CylC: Cylindrotheca closterium; DelM: Delphineis minutissima; EntC: Entomoneis corrugate; FalS: Fallacia scaldensis; GyrA: Gyrosigma acuminatum; GyrL: Gyrosigma cf. limosum; GyrF: Gyrosigma fasciola; NavA: Navicula abscondita; NavAl: Navicula aitchelbee; NavG: Navicula germanopolonica; NavGR: Navicula gregaria; NavP:Navicula perminuta; NavPH: Navicula phylleptosoma; NavS: Navicula sp.1; NitA: Nitzschia aequorea; NitP: Nitzschia panduriformis var.continua; PleA: Pleurosigma angulatum; SkeC: Skeletonema costatum; SurB: Surirella brebissonii; ThaV: Thalassiosira cf. visurgis; The lines with empty arrowhead and bold labels indicate the environmental factors: D50:diameter of 50\%

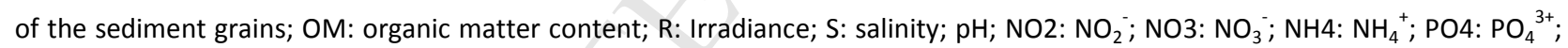
$\mathrm{Zn}: \mathrm{Zn}^{2+} ; \mathrm{Si}: \mathrm{Si}(\mathrm{OH})_{4}$.

The DCCA axis1 explained $40.5 \%$ of the total variance, and was correlated with environmental data at $r=0.991$, and most importantly with environment variables of heavy metals $\left(\mathrm{Zn}^{2+}, r=-0.969\right)$, D50 (average grain size of sediment, $r=0.866)$, OM (organic matter, $r=-0.841$ ) and $\mathrm{Si}(\mathrm{OH})_{4}(r=-0.630)$. The DCCA axis2 accounts for $15.5 \%$ of total variance, and was correlated with environmental data at $r=0.901$, and the individual variables were $\mathrm{R}$ (irradiance, $r=0.701), \mathrm{S}$ (salinity, $r=0.674), \mathrm{pH}(r=-0.596)$, and the nutrient of $\mathrm{PO}_{4}{ }^{3+}(r=0.566)$ and $\mathrm{Si}(\mathrm{OH})_{4}(\mathrm{r}=0.556)$. Among the displayed top 11 environmental variables, heavy metals $\left(\mathrm{Zn}^{2+}\right)$ had positive correlation with organic matter $(r=0.888)$ and a negative relation with D50 $(r=-0.850)$; salinity positively related to irradiance $(r=0.901)$ and negatively to $\mathrm{pH}$ and $\mathrm{NO}_{n}^{-}(r=-0.714$ and -0.747$)$; $\mathrm{pH}$ was positively related to $\mathrm{NO}_{3}{ }^{-}$and $\mathrm{NO}_{2}{ }^{-}(r=0.581$ and 0.749$)$; and $\mathrm{NO}_{3}{ }^{-}$and $\mathrm{NO}_{2}{ }^{-}$were closely related to each other $(r=0.703), \mathrm{PO}_{4}{ }^{3+}, \mathrm{NH}_{4}{ }^{+}$and $\mathrm{Si}(\mathrm{OH})_{4}$ were also positively correlated with each other $(r=0.900,0.815,0.703$, respectively).

The DCCA biplot and based on multivariate correlation analysis, indicated that D50 was positively correlated with some species abundant in sand sediments of site Re, especially significantly for 7 species Achnantheiopsis 
delicatulum, Amphora hassiaca, Anorthoneis pulex, A. vortex, Fallacia scldensis, Navicula germallopolnica and N. Perminuta $(p<0.01)$. Heavy metals (represented by $\mathrm{Zn}^{2+}$ ) were significant positively related to most of species, especially very closely with Entomoneis corrugate, Gyrosigma cf.limosum, N. aitchelbee and Navicula sp.1 $(p<0.01)$. In addition to species closely related to heavy metals, species $N$. gregaria were more strongly correlated to organic matter $(r=0.729, p<0.01)$. Salinity contributed to variation of whole community but was only significantly related to a few species of Amphora hassiaca $(r=0.520, p<0.01)$ and Navicula abscondita $(r$ $=-0.764, p<0.01$ ). Species Cylindrotheca closterium, Navicula abscondita, N. phylleptosoma and Surirella brebissonii were positively correlated to high $\mathrm{Si}(\mathrm{OH})_{4}$ and $\mathrm{NH}_{4}{ }^{+}$nutrient $(p<0.05)$. The species Gyrosigma acuminatum and Surirella brebissonii were also closely related to $\mathrm{PO}_{4}{ }^{3+}$ and $\mathrm{NH}_{4}{ }^{+}(p<0.01)$. Although lacking high Pearson correlation values, Gyrosigma fasciola, N. germanopolonica and N. perminuta were significantly negative related to $\mathrm{Si}(\mathrm{OH})_{4}(r=-0.514 \sim-0.547, p<0.01)$, and Amphora hassiaca and Anorthoneis pulex were significantly negatively related to $\mathrm{NO}_{2}^{-}(r=-0.489,-0.484, p<0.01)$. However, species such as the most abundant species Navicula consentanea were excluded from the biplot because they had little effect on the variation of MPB community. Factors such as sediment temperature that had strong relationship with irradiance $(r=0.925, p<0.01),<63 \mu \mathrm{m} \%$ sediment that was significantly negative to D50 $\left(r=-0.920^{* *}, p<0.01\right)$ and water content that was significantly positive related to $63 \mu \mathrm{m} \%\left(r=0.968^{* *}, p<0.01\right)$ were not selected in the biplot due to their high multicollinearity with other variable by VIF $>40$.

Univariate correlations revealed the relationships between community structural parameters with the 10 most influential environmental variables. The species diversity and evenness had no significant correlation with these environmental factors. The species number were strongly positively correlated with organic matter $(0.542, p<$ 0.01 ), and species richness were significantly correlated with organic matter, heavy metals (proxy of $\mathrm{Zn}^{2+}$ ) and $\mathrm{NH}_{4}{ }^{+}(0.656,0.587,0.536$, respectively, $p<0.01)$.

\section{Discussion}

\subsection{Distribution characteristics of MPB community}

The temporal/spatial variations in MPB species distribution are commonly related to a complex set of interactions with environmental conditions (Kromkamp et al., 2006; MacIntyre et al., 1996; Underwood and Kromkamp, 1999; Underwood et al., 1998). Among those variables, compared to other rapidly fluctuating abiotic factors, such as nutrients, salinity and water contents, sediment grain size composition remains relatively stable, and previous studies have identified close relationships between sediment composition and the MPB community (e.g. Cahoon et al., 1999; Facca and Sfriso, 2007; Mitbavkar and Anil, 2002; Oh and Koh, 1995; Du et al., 2010, 2012). In the present study, close relationships of MPB community not only were revealed with sediment grain size (D50), but also with other main environmental factors, such as irradiance, salinity, organic matter, heavy metals concentrations and nutrient of $\mathrm{NH}_{4}{ }^{+}, \mathrm{PO}_{4}{ }^{3+}$, and $\mathrm{Si}(\mathrm{OH})_{4}$. On the other hand, the absolute predominance of the genus Navicula (species as $N$. consentanea and $N$. gregaria) was consistent with studies in most coastal area of temperate to subtropical zone (Oh and Koh, 1995; Du et al., 
2009; Montani et al., 2003; Easley et al., 2005; Haubois et al., 2005). MPB assemblages at study sites could also be characterized according to the sediment types and other main environmental conditions, with respectively typical species as demonstrated in our previous studies (Du et al., 2009 and 2016).

In this study, the MPB biomass was strongly related to the sediment composition and positively related to grain size D50 and negatively correlated to sediment of $<63 \mu \mathrm{m}$, which is contrary to most previous studies (Du et al., 2010; Lundkvist et al., 2007; Miller et al., 1996; Paterson, 1989). It implied that sediment with larger grain size, such as site Re, had higher MPB biomass than muddy sediment, although a typical golden-brown biofilm was visible by naked eyes at site $\mathrm{Ag}$ in winter but in neither seasons at site Re (observed personally). In addition to the difference of sampling periods and study regions, one reason might due to the method for the calculation chlorophyll $a$ concentration which was transferred from freeze dried sediment methodology to that of fresh sediment, where MPB biomass was relatively diluted by interstitial water in volumetric mass ( $\mu \mathrm{g} \mathrm{chl} a \mathrm{~mL}^{-1}$ ). On the other hand, sandy sediments could supply more tridimensional space for MPB (Du et al., 2010). Another reason might be stronger grazing pressure by benthic animals in muddy sediment of site $\mathrm{Ag}$, which was indicated by the higher pheo-pigments and lower chl a/peo-pigments.

The negative correlation between MPB biomass and heavy metals in the present study, and significant influence of heavy metals on MPB species composition suggested further concern for pollution effects on coastal systems. Negative correlation between MPB biomass and nutrient such as concentrations of $\mathrm{Si}(\mathrm{OH})_{4}$ and $\mathrm{NH}_{4}{ }^{+}$in porewater were similar to previous studies with significant but low coefficients (Welker et al., 2002; Skinner et al., 2006; Facca and Sfriso, 2007). A clear inverse relation was observed between $\mathrm{NO}_{n}^{-}$and $\mathrm{MPB}^{-}$ biomass in sublittoral sediments of the Gulf of Trieste, northern Adriatic Sea (Cibic et al, 2007). Nevertheless, $\mathrm{NO}_{n}{ }^{-}, \mathrm{PO}_{4}{ }^{3+}$ had no significant correlation to MPB biomass in the present study, similarly four nutrients $\left(\mathrm{Si}(\mathrm{OH})_{4}\right.$ and $\mathrm{NH}_{4}{ }^{+} \mathrm{NO}_{n}{ }^{-}, \mathrm{PO}_{4}{ }^{3+}$ ) in porewater had no significant relations with MPB biomass in intertidal flats of Nakdong estuary, South Korea (Du et al., 2009). The large oscillations of nutrient concentrations in intertidal sediment (Kuwae et al., 2003; Sakamaki et al., 2006) and MPB themselves influencing the sediment-water interface nutrient fluxes (Rysgaard et al., 1995) may contribute to these phenomena.

\subsection{MPB community and environmental quality status}

Multivariate analyses were applied in the present study for assessing the relationship of species composition with environmental factors. Multivariate approaches are more effective than univariate analyses for analyzing temporal/spatial variations in community structure and relationships to environmental variables (Clarke and Ainsworth, 1993; Jiang et al., 2014; Xu et al., 2012 a, b). The differences between communities or species distributions on spatial and temporal scales and their variation along gradients of environmental conditions were well illustrated through the multivariate approaches. In coastal intertidal ecosystems, which are notably affected by anthropogenic impacts, multivariate analysis of MPB was a suitable tool to assess the environmental quality status. 
At the community level, based on the variation in species composition and environmental variables, the separation of MPB assemblages could contribute understanding the divergence on environmental status. In the present study, the assemblages of site Re and Ag were mainly distinguished by the grain size of sediment, heavy metal concentration and organic matter. The assemblage of site Ay was more affected by irradiance, $\mathrm{pH}$ and $\mathrm{PO}_{4}{ }^{3+}$. The seasonal differences in MPB communities of summer and winter groups at site Ay could be explained by the variation in environmental variables of grain size of sediment, heavy metal concentration, salinity and $\mathrm{NO}_{3}{ }_{3}^{-}$. The separation of seasonal groups of site $\mathrm{Ag}$ could be attributed to differences in $\mathrm{Si}(\mathrm{OH})_{4}$, $\mathrm{NH}_{4}{ }^{+}$and $\mathrm{NO}_{3}{ }^{-}$. In general, the MPB communities presented clear spatial and temporal distribution of 61 MPB species, and especially the 25 most influenced species, reflecting the differences of environmental factors in coastal area of Pertuis Charentais (France). Facca and Sfriso (2007) also pointed out that the community structure, particularly the abundance of opportunistic species, offered the possibility to distinguish the anthropic pressures on the ecosystem of shallow coastal areas. On the other hand, the community-based ecological parameters (e.g., species richness, diversity, and evenness) have also been employed in field investigations and used to assess environmental quality status (Huston, 1979; Ismael and Dorgham, 2003; Xu et al., 2014). In the present study, the indices of diversity and evenness showed no difference among all samples, however, the species richness was relative higher in muddy sites with higher nutrient of $\mathrm{NH}_{4}{ }^{+}$, organic matter and heavy metals $\left(\mathrm{Zn}^{2+}\right)$, the species number was also significantly positively related to organic matter. This implied that higher species number and richness might indicate relatively higher nutrient levels in the coastal area. Therefore, the distribution characteristics of MPB communities combining with community-based ecological index could reflect environmental quality status and have the potential for use in bioassessment of coastal intertidal ecosystems.

At the species level, distinctive species which significantly correlated to specific environmental variable may be considered as potential bioindicators. Firstly, with regard to certain sediment type of grain size composition, three of 7 species (Navicula germanopolnica, N. perminuta and Fallacia scaldensis) were closely related to D50 characterized sandy sediment. The relatively larger and longer species Gyrosigma fasciola, G. acuminatum, N. gregaria and $N$. phylleptosoma which were negatively related to D50 but positively to $<63 \mu \mathrm{m}$ were dominant in muddy sediment. In a study of the intertidal MPB community in Nakdong estuary, the small diatom $N$. ramosissium (ca. $35 \times 8 \mu \mathrm{m}$ ) linearly correlated to medium and fine sand (125 - $500 \mu \mathrm{m}$ ) (Du et al., 2009). In study of Skinner et al. (2006), species Cyclotella sp. and Entomoneis alata were associated with the percentage of very fine sand $(63-125 \mu \mathrm{m})$. Four species (Amphora coffeaeformis, Gyrosigma acuminatum, Cymbella turgidula and Thalassiosira eccentric) were proved significantly positive correlated to the percentage of grain size $<63 \mu \mathrm{m} \%$, but Hantszchia amphioxys and Nizshia sp2. were negatively related (Du et al., 2016). Although the characteristic species for sediment types varied among difference study regions, the general relationship was consistent, e.g. large and long epipelic diatom indicate finer sediment $<125 \mu \mathrm{m}$, and small species represent coarser sediments > $125 \mu \mathrm{m}$ (Oh and Koh, 1995; Mitbavkar and Anil, 2002; Skinner et al., 2006; Du et al., 2009). 
With respect to nutrients, there is considerable literature demonstrating the strong preferences of certain taxa for particular levels of specific nutrients (Underwood et al., 1998; Sullivan, 1999), although few studies determined an explicit indicator function for diatom species in open coastal areas due to the complicated environmental conditions. The centric diatom Thalassiosira sp., which represented one of the most abundant genus and was dominant close to the mainland where the pollutant discharge is high, was suggested as important bioindicator for assessing the trophic status (Facca and Sfriso, 2007). A study carried on the Ems-Dollard estuary showd increases in the relative abundance of Navicula phyllepta, N. flanatica and Pleurosigma angulatum with decreasing ammonium $\left(\mathrm{NH}_{4}{ }^{+}\right)$concentrations due to the installation of waste treatment processes by industry (Peletier, 1996). In the oligotrophic Van Stadens Estuary, South Africa, Planothidium delicatulum and Petroneis humerosa were closely associated with porewater $\mathrm{NH}_{4}{ }^{+}$ concentrations (Skinner et al., 2006). In the study of Du et al. (2016), Navicula lacustris and Fragilaria sp.1 were significantly negatively correlated to $\mathrm{NH}_{4}{ }^{+}$concentration. In the present study, without obvious pollution of waste water, Navicula abscondita, Surirella brebissonii and Cylindrotheca closterium were significantly positive related to $\left[\mathrm{NH}_{4}^{+}\right]$, and Gyrosigma acuminatum and Surirella brebissonii also closely related to $\mathrm{NH}_{4}{ }^{+}$ concentration. $\mathrm{N}$ compounds of $\mathrm{NO}_{n}{ }^{-}$showed negative relationships with many species, such as Nitzschia sigma and N. dissipata and other species of Navicula, Nitzschia (Kotsedi, 2011) and Pleurosigma anglulatum (Du et al., 2016). In the present study, it was Amphora hassiaca and Anorthoneis pulex negative to $\mathrm{NO}_{2}^{-}$. With regards to $\mathrm{Si}$ $(\mathrm{OH})_{4}$, which is usually abundant in sediment, Du et al. (2016) showed Pleurosigma angulatum was negatively correlated to $\mathrm{Si}(\mathrm{OH})_{4}$, however, in this study, it was Gyrosigma fasciola, N. germanopolonica and N. perminuta significantly negatively but Navicula abscondita, Surirella brebissonii and Cylindrotheca closterium significantly positively related to $\mathrm{Si}(\mathrm{OH})_{4}$. The species Gyrosigma acuminatum and Surirella brebissonii were closely related to $\mathrm{PO}_{4}{ }^{3+}$. This demonstrates that various species have specific relationships with certain nutrients under different environmental conditions.

Furthermore, using the gradient of salinity and nutrient concentration along river estuary to the fully marine system, several studies explore the relationship of diatom function to environmental status. Nodine and Gaiser (2014) indicated that diatom assemblages of 18 indicator taxa were strongly related to environmental variables such as total phosphorus (TP), and total nitrogen (TN) within the subregions of the investigated three rivers and a harbor. Salinity was the predominant driver of difference among diatom assemblages across the catchment. These relationships were evaluated for predicting the environmental status by the diatom assemblages (Nodine and Gaiser, 2014). Along with gradient in eutrophication on a tidal flat, Navicula gregaria, Nitzschia sigma, and Nitzschia tryblionella proved to be tolerant of pollution, even nutrient-loving for the former two species, while the genera Achnanthes and Amphora were typical in the nutrient-poor regions (Agatz et al., 1999). Along a saltmarsh creek, diatoms Nitzschia sigma and Gyrosigma limosum and the cyanobacteria Oscillatoria limosa and $O$. princeps had significantly higher population densities near the sewage outfall, and Navicula phyllepta, N. pargemina, Nitzschia frustulum, Cylindrotheca signata and Pleurosigma angulatum were significantly more abundant at the seaward end of the gradient. Laboratory experiments 
supported the field observation and emphasized the importance of ammonium concentration for trophic preferences (Underwood et al., 1998). In the present study, although without obvious gradients, salinity created significant difference among three sites and two seasons except for site Re and $\mathrm{Ag}$ in summer, and contributed to the main variation of MPB community revealed by DCCA and was also significantly related to species of Amphora hassiaca and Navicula abscondita. In the study of Du et al. (2016), Navicula lacustris and Pleurosigma anglulatum were significantly positive, and Leptocylindrys sp.1 was significantly negatively correlated to salinity.

In general, these potential indicator species had site specific variation among the different study areas, but with accumulating and categorizing more data, general indicators of diatom assemblages might be designated. For instance, comparing with the above studies, the negative relationship of Pleurosigma anglulatum with ammonium or $\mathrm{NO}_{n}^{-}$, and its positive relationship with salinity was shown, and Nitzschia sigma was pollutant-tolerant (Agatz et al., 1999; Underwood et al., 1998). These findings suggest that the presence/dominance of these species may be considered as a potential bioindicator for determining the environmental status of coastal intertidal ecosystems. However, to designate a bioindicator, further field and laboratory studies need to be carried out, especially for coastal areas where many factors fluctuate such as hydrodynamic conditions (tides and currents). It requires frequent observations before the sensitivity to pollution of each taxon (genus or species) is measured and its role as water quality indicator recognized. This is why existing methodologies for diatom bioindicators are mainly limited in freshwater systems, representing by the Trophic Diatom Index (TDI; Kelly, 1995) which is recognized by United Kingdom legislation as a reliable tool to assess river quality. On the contrary, only a very few studies used the transitions of estuary and wetland to marine system for exploring bioindicator systems as discussed above (Underwood et al., 1998; Agatz et al., 1999; Nodine and Gaiser, 2014). Therefore, using benthic diatoms as water quality indicator in coastal area routinely needs further standardized investigation methodology.

In the present study, fifteen heavy metals were analyzed their correlations with MPB assemblages. The positive correlation of species Entomoneis corrugate, Gyrosigma cf. limosum, Navicula aitchelbee with heavy metals (represented by $\mathrm{Zn}^{2+}$ ) implied that at least these species tolerate heavy metals and could be focused further as potential indicators for higher heavy metals concentration. Previous studies on heavy metals pollution with high excess concentration caused the deformation of diatoms. It proved that the deformity frequency of Navicula rhyncocephala, Achnanthes hauckiana, Fragilaria capucina, and Diatoma vulgare was significantly lower at unpolluted sites than at polluted sites (Dickman, 1998). In addition, several publications showed that the diatoms had the ability to adapt/resist environmental heavy metals, not only requiring certain metals as essential elements or showing tolerance through physiology, but also by the restructuring of diatom communities under metal stress (Masmoudi et al., 2013). In the present study, the heavy metals concentrations were almost lower by an order of magnitude than those of in study of Dickman (1998) and review of Masmoudi et al.(2013), and the strongly multi-collinearity among the variations of 15 heavy metal ions handicapped finding the relationship between individual heavy metal and species. However, it provided a base on the 
influence of heavy metals on MPB species composition and a possibility of potential species indicating the level of heavy metals concentrations.

In general, based on our study, there is potential for using MPB to assess the environmental status at a community level, i.e. discriminating environmental quality status using community pattern of MPB. The MPB species that were significantly correlated with individual environmental factors may be used as a potential bioindicator. However, it should be noted that the identification of MPB requires skilled taxonomic experts, and the numeration of MPB is time-consuming, especially for environmental agencies that are often dealing with large spatial/temporal scales in a limited time span. Molecular methods have been tried in this area (Jahn et al., 2007; Kaczmarskaet al., 2007; McGregor, 2010; Moniz and Kaczmarska, 2010; Trobajo et al., 2010; Hamsher et al., 2011), however, due to the low universal and quantification efficiency based on amplification of environmental samples, there is still a handicap for the practical situation (Regine et al., 2007; Guo et al., 2016). Accompanying the development of new ideas and techniques, further research will promote the application of bioassessment of environmental quality status using MPB community for coastal ecosystems

\section{Conclusions}

The MPB community structures showed spatial and temporal variation patterns in the coastal area of Pertuis Charentais (La Rochelle, France). The variation in MPB communities significantly correlated with environmental variables, especially sediment grain size composition, heavy metals, irradiance, salinity and $\mathrm{PO}_{4}{ }^{3+}$ and $\mathrm{Si}(\mathrm{OH})_{4}$, indicating the difference in environmental quality status. The species number and richness might be used as a community level index for high organic matter and ammonium concentration in assessing the quality of environmental status. Particular species could be considered as potential bioindicator for specific environmental factor, such as Anorthoneis pulex, Fallacia scldensis, Navicula germallopolnica for larger grain size, Entomoneis corrugate, Navicula aitchelbee and Gyrosigma cf. limosum for heavy metals, Navicula phylleptosoma and Surirella brebissonii for $\mathrm{Si}(\mathrm{OH})_{4}$ and $\mathrm{NH}_{4}{ }^{+}$, as well as $\mathrm{G}$. acuminatum and S. brebissonii for $\mathrm{PO}_{4}{ }^{3+}$ and $\mathrm{NH}_{4}{ }^{+}$. It suggested that MPB communities may be used as a potential bioindicator for assessing environmental quality status in coastal intertidal ecosystems.

\section{Acknowledgements}

This research was supported financially by the research program of Région Poitou-Charentes, France, and the National Natural Science Foundation of China (41276137). 


\section{References}

Aleem, A.A. (1950). The diatom community inhabiting the mud-flats at Whitstable. New Phytologist, 49:174188.

Admiraal, W. \& Peletier, H., (1980). Distribution of diatom species on an estuarine mud flat and experimental analysis of the selective effect of stress. Journal of Experimental Marine Biology and Ecology 46: 157-175.

Agatz, M., Asmus, R.M. \& Deventer, B. (1999). Structural changes in the benthic diatom community along a eutrophication gradient on a tidal flat. Helgoland Marine Research, 53: 92-101.

Aminot A. \& Kérouel, R. (2007). Dosage automatique des nutriments dans les eaux marines: méthodes en flux continu. Méthodes Danalyse En Milieu Marin. Ifremer, Nantes.

Barranguet, C., Kromkamp \& J. Peene, J. (1998). Factors controlling primary production and photosynthetic characteristics of intertidal microphytobenthos. Marine Ecology Progress Series, 173:117-126.

Blanchard, G.F., Guarini, J., Orvain M., F. \& Sauriau, P.G. (2001). Dynamic behaviour of benthic microalgal biomass in intertidal mudflats. Journal of Experimental Marine Biology and Ecology, 264: 85-100.

Brotas, V., Cabrita, T., Portugal, A., Serôdio, J. \& Catarino, F. (1995). Spatio-temporal distribution of microphytobenthic biomass in intertidal flats of Tagus estuary. Hydrobiologia, 300/301: 93-104.

de Brouwer, J.F.C., Bjelic, S., de Deckere, E.M.G.T. \& Stal, L.J. (2000). Interplay between biology and sedimentology in a mudflat (Biezelingse Ham, Westerschelde, The Netherlands). Continental Shelf Research 20: 1159-1177.

Cahoon, L.B., Nearhoof, J.E. \& Tilton, C.L. (1999). Sediment grain size effect on benthic microalgal biomass in shallow aquatic ecosystems. Estuaries and Coasts, 22:735-741.

Chen, X., Zhou, W., Pickett, S.T.A., Li, W., Han, L. \& Ren, Y. (2016) Diatoms are better indicators of urban stream conditions: A casestudy in Beijing, China. Ecological Indicators, 60: 265-274.

Christie, M., Dyer, K., Blanchard, G., Cramp, A., Mitchener, H. \& Paterson, D.M. (2000). Temporal and spatial distributions of moisture and organic contents across as macro-tidal mudflat. Continental Shelf Research, 20: 1219-1241.

Cibic, T., Blasutto, O., Falconi, C. \& Umani, S.F. (2007). Microphytobenthic biomass, species composition and nutrient availability in sublittoral sediments of the Gulf of Trieste. Estuarine, Coastal and Shelf Science,75: 50-62.

Clarke, K.R. \& Ainsworth, M. (1993). A method of linking multivariate community structure to environmental variables. Marine Ecology Progress Series, 92: 205-219.

Cochero, J., Licursi, M. \& Gómez, N. (2015). Changes in the epipelic diatom assemblage in nutrient rich streamsdue to the variations of simultaneous stressors. Limnologica, 51: 15-23 
Dickman, M.D. (1998). Benthic marine diatom deformities associated with contaminated sediments in Hong Kong. Article in Environment International, 24(7):749-759.

Du, G.Y., Chung, I.K. \& Xu, H.L. (2016). Insights into community-based bioassessment of environmental quality status using microphytobenthos in estuarine intertidal ecosystems. Acta Oceanologica Sinica, 35(6):112120.

Du, G.Y., li, W.T., Li, H.B. \& Chung, I.K. (2012). Migratory response of estuarine benthic diatoms to light and temperature monitored by chlorophyll fluorescence. Journal of Plant Biology, 55: 159-164.

Du, G.Y., Son, M., Yun, M., An, S. \& Chung, I.K. (2009). Microphytobenthic biomass and species composition in intertidal flats of the Nakdong River estruary, Korea. Estuarine, Coastal and Shelf Science, 82: 663-672.

Du, G.Y., Son, M., An, S. \& Chung, I.K. (2010). Temporal variation in the vertical distribution of microphytobenthos in intertidal flats of the Nakdong River estuary, Korea. Estuarine, Coastal and Shelf Science, 86: 62-70.

Facca, C. \& Sfriso, A. (2007). Epipelic diatom spatial and temporal distribution and relationship with the main environmental parameters in coastal waters. Estuarine, Coastal and Shelf Science, 75:35-49.

Forster, R. M., Créach,V., Sabbe, K., Vyverman, W. \& Stal, L. J. (2006). Biodiversity-ecosystem function relationship in microphytobenthic diatoms of the Westerschelde estuary. Marine Ecology Progress Series, 311: 191-201.

Guarini, J.M., Blanchard, G.F., Bacher, C., Gros, P., Riera, P., Richard, P., Gouleau, D., Galois, R., Prou, J. \& Sauriau, P. G. (1998). Dynamics of spatial patterns of microphytobenthic biomass: inferences from a geostatistical analysis of two comprehensive surveys in Marennes-Oléron Bay (France). Marine Ecology Progress Series, 166: 131-141.

Hamsher, S.E., Evans K.M., Mann, D.G., Pouličková A. \& Saunders G.W. (2011). Barcoding Diatoms: Exploring Alternatives to COI-5P. Protist, 162: 405-422.

Haubois, A.-G., Sylvestre, F., Guarini, J.-M., Richard, P. \& Blanchard, G.F. (2005). Spatio-temporal structure of the epipeplic diatom assemblage from an intertidal mudflat in Marennes-Oléron Bay, France. Estuarine, Coastal and Shelf Science, 64: 385-394.

Herlory, O., Guarini, J.M., Richard, P. \& Blanchard, G.F. (2004). Microstructure of microphytobenthic biofilm and its spatio-temporal dynamics in an intertidal mudflat (Aiguillon Bay, France). Marine Ecology Progress Series, 282: 33-44.

Hustedt, F. \& Jensen, N.G. (1985). The pennate diatoms (A translation of Hustedt's “Die Kieselagen" 2 Tiel with a supplement by Jensen N.G.). Koeltz Scientific Books, Koenighstein.

Huston, M. (1979). A general hypothesis of species diversity. The American Naturalist, 113: 81-101. 
Intergovernmental Oceanographic Commission, International Council of Scientific Unions, Scientific Committee on Oceanic Research. (1994). Protocols for the Joint Global Ocean Flux Study (JGOFS) Core Measurements. UNESCO, Paris.

Ismael, A.A. \& Dorgham, M.M. (2003). Ecological indices as a tool for assessing pollution in El-Dekhaila Harbour (Alexandria, Egypt). Oceanologia, 45:121-131.

Jahn, R., Zetzsche, H., Reinhardt R. \& Gemeinholzer B. (2007). Diatoms and DNA barcoding: A pilot study on an environmental sample. In Proceedings of the 1st Central European Diatom Meeting 2007 (Kusber, W.-H. \& Jahn, R. editors). Botanic Garden and Botanical Museum Berlin-Dahlem, Freie Universität Berlin.

Jiang, Y., Xu H.L. \& Warren, A. (2014). Insights into discriminating environmental quality status using taxonomic distinctness based on a small species pool of ciliated protozoa in marine ecosystems. Science of the Total Environment, 468-469: 663-670.

de Jonge, V. N. \& Colijn, F. (1994). Dynamics of microphytobenthos biomass in the Ems estuary. Marine Ecology Progress Series, 104: 185-196.

Katherine, B. \& Stephanie, G. (2005) The use of epilithic and epiphytic diatoms as indicators of organic pollution in the Cheboygan River Michiga. In Agris. http://deepblue.lib.umich.edu/bitstream/2027.42/ 55043/ 1/3487.pdf

Kaczmarska, I., Reid, C. \& Moniz, M. (2007). Diatom taxonomy: morphology, molecules and barcodes... In Proceedings of the 1st Central European Diatom Meeting 2007 (Kusber, W.-H. \& Jahn, R. editors), Botanic Garden and Botanical Museum Berlin-Dahlem, Freie Universität Berlin.

Kelly, M., Bennion, H., Burgess, A., Ellis, J., Juggins, S., Guthrie, R., Jamieson, J., Adriaenssens, V. \& Yallop, M. (2009). Uncertainty in ecological status assessments of lakes and rivers using diatoms. Hydrobiologia, 633: $5-15$

Kelly, M.G. \& Whitton, B. A. (1995). The Trophic Diatom Index: A New Index for Monitoring Eutrophication in Rivers. Journal of Applied Phycology, 7:433-444.

Kotsedi, D. (2011). The response of micaroalgal biomass and community composition to environmental factors in Sundays Estuary (Thesis). Nelson Mandela Metropolitan University, Port Elizabeth.

Kromkamp, J.C., de Brouwer, J.F.C., Blanchard, G.F., Forster, R.M. \& Créach, V. (2006). Functioning of microphytobenthos in estuaries. Royal Netherlands Academy of Arts and Sciences, Amsterdam.

Kuwae, T., Kibe, E. \& Nakamura, Y., (2003). Effect of emersion and immersion on the porewater nutrient dynamics of an intertidal sandflat in Tokyo Bay. Estuarine, Coastal and Shelf Science, 57: 929-940.

Lavoie, I., Campeau, S., Grenier, M. \& Dillon, P. (2006). A diatom-based index for water quality assessment in eastern Canada: an application of Canonical Analysis. Canadian Journal of Fisheries and Aquatic Sciences, 
63:1793-1811.

Guo, L.L., Sui, Z.H. \& Liu, Y. (2016). Quantitative analysis of dinoflagellates and diatoms community via Miseq sequencing of actin gene and v9 region of 18S rDNA. Scientific Reports, 6:34709, DOI: 10.1038/srep34709.

Lorenzen, C.J. (1967). Determination of chlorophyll and pheo-pigments: Spectrophotometric Equations. Limnology and Oceanography, 12: 343-346.

Lundkvist, M., Grue, M., Firend, P.L. \& Flindt, M.R. (2007). The relative contribution of physical and microbiological factors to cohesive sediment stability. Continental Shelf Research, 27:1143-1152.

MacIntyre, H.L., Geider, R.J. \& Miller, D.C. (1996). Microphytobenthos: The ecological role of the "secret garden" of unvegetated, shallow-water marine habitats. I. Distribution, abundance and primary production. Estuaries and Coasts, 19: 186-201.

Masmoudi, S., Nguyen-Deroche, N., Caruso A., Ayadi H., Morant-Manceau A., Tremblin G., Bertrand M. \& Schoefs B. (2013). Cadmium, copper, sodium and zinc effects on diatoms: from heaven to hell-A review. Cryptogamie Algologie, 34 (2): 185-225.

Méléder, V., Rincé, Y., Barillé, L, Gaudin,P. \& Rosa, P. (2007). Spatio-temporal changes in microphytobenthos assemblages in a macrotidal flat (Bourgeneuf Bay, France). Journal of Phycology, 43: 1177-1190.

Miller, D.C., Geider, R.J. \& MacIntyre, H.L. (1996). Microphytobenthos: The ecological role of the "secret garden" of unvegetated, shallow-water marine habitats. II. Role in sediment stability and shallow-water food webs. Estuaries and Coasts, 19: 202-212.

Mitbavkar, S. \& Anil, A.C. (2002). Diatoms of the microphytobenthic community: population structure in a tropical intertidal sand flat. Marine Biology, 140: 41-57.

Mitbavkar, S. \& Anil, A.C. (2006). Diatoms of the microphytobenthic community in a tropical intertidal sand flat influenced by monsoons: spatial and temporal variations. Marine Biology, 148: 693-709.

Moniz, M.B.J. \& Kaczmarska I. (2010). Barcoding of Diatoms: Nuclear Encoded ITS Revisited. Protist, 161: 7-34.

Nodine, E.R. \& Gaiser, E.E. (2014). Distribution of Diatoms along environmental gradients in the Charlotte Harbor, Florida (USA), esturary and its watershed: Implications for bioassessment of salinity and nutrient concentrations. Estuaries and Coasts, 37(4): 864-879.

Oh, S.H. \& Koh, C.H. (1995). Distribution of diatoms in the surficial sediments of the Mangyung-Dongjin tidal flat, west coast of Korea (Eastern Yellow Sea). Marine Biology, 122: 487-496.

Oppenheim, D.R. (1988). The distribution of epipelic diatoms along an intertidal shore in relation to principal physical gradients. Botanica Marina, 31: 65-72.

Paterson, D.M. (1989). Short-term changes in the erodibility of intertidal cohesive sediments related to the migratory behaviour of epipelic diatoms. Limnology and oceanography, 34: 223-234. 
Potapova, M. \& Charles, D.F. (2007). Diatom metrics for monitoring eutrophication inrivers of the United States. Ecological Indicators, 7: 48-70.

Propp, M.V., Tarasoff, V.G., Cherbadgi, I.I. \& Lootzik, N.V. (1980). Benthic-pelagic oxygen and nutrient exchange in a coastal region of the Sea of Japan. In Marine Benthic Dynamics (Tenore, K.R. \& Coull, B.C., editors), 265-284. University of South Carolina Press, Columbia.

Ribeiro, L. (2010). Intertidal benthic diatoms of the Tagus estuary: taxonomic composition and spatial-temperal variation (Thesis). Universidade De Lisboa, Lisboa.

Round, F.E. (1979). A diatom assemblage living below the surface of inter tidal sand flats. Marine Biology, 54: 219-223.

Round, F. E., Crawford, R.M. \& Mann, D. G. (1990). The Diatoms. Cambridge University Press, New York.

Rysgaard, S., Christensen, P.B. \& Nielsen, L.P. (1995). Seasonal variation in nitrification and denitrificaiton in estuarine sediment colonized by benthic microalgae and bioturbatinginfauna. Marine Ecology Progress Series, 126:111-121.

Sabbe, K. (1993). Short-term fluctuations in benthic diatom numbers on an intertidal sandflat in the Westeschelde estuary (Zeeland, the Netherlands). Hydrobiologia, 269-270: 275-284.

Seeberg-Elverfeldt, J., Schlüter, M., Feseker, T. \& Kölling, M. (2005). Rhizon sampling of porewaters near the sediment-water interface of aquatic systems. Limnology and Oceanography-Methods, 3:361-371.

Serôdio, J. \& Catarino, F. (1999). Fortnightly light and temperature variability in estuarine intertidal sediments and implications for microphytobenthos primary productivity. Aquatic Ecology, 33: 235-241.

Serôdio, J. \& Catarino, F. (2000). Modelling the primary productivity of intertidal microphytobenthos: time scales of variability and effects of migratory rhythms. Marine Ecology Progress Series, 192: 13-30.

Skinner, T., Adams,J.B. \& Gama, P.T. (2006).The effect of mouth opening on the biomass and community structure of microphytobenthos in a small oligotrophic estuary. Estuarine, Coastal and Shelf Scienc, 70:161-168.

Smol, J. P. \& Stoermer, E. F. (2010). The Diatoms: Applications for the environmental and earth sciences. 2nd edition. Cambridge University Press, Cambridge.

Solimini, A.G., Cardoso, A.C \& Heiskanen, A.S. (2006). Indicators and methods for the ecological status assessment under the Water Framework Directive. EUR 22314EN. Office for Official Publications of the European Communities, Luxembourg.

Spilmont, N., Davoult, D. \& Migné, A. (2003). Benthic primary production during emersion: In situ measurements and potential primary production in the Seine Estuary (English Channel, France). Marine Pollution Bulletin, 53: 49-55. 
Stevenson, R.J., Pan, Y., Manoylov, K.M., Parker, C.A., Larsen, D.P. \& Herlihy, A.T. (2008).Development of diatom indicators of ecological conditions for streams of thewestern US. Journal of the North American Benthological Society, 27:1000-1016.

Stevenson, R.J., Pan, Y. \& Van Dam, H. (2010). Assessing environmental conditions in rivers and streams with diatoms. In The Diatoms: Applications for the Environmental and Earth Sciences (Smol, J.P. \& Stoermer, E.F., editors.), 57-85. Cambridge University Press, Cambridge.

Taylor, J.C., de la Rey P.A. \& van Rensburg L. (2005). Recommendations for the collection, preparation and enumeration of diatoms from riverine habitats for water quality monitoring in South Africa. African Journal of Aquatic Science, 30: 65-75.

Ter Braak, C.J.F. \&Šmilauer, P. (2002): CANOCO Reference Manual and CanoDraw for WindowsUser's Guide: Software for Canonical Community Ordination (version 4.5). Ithaca, NY: Microcomputer Power.

Thornton, D.C.O., Dong, L.F., Underwood, G.J.C. \& Nedwell, D.B. (2002). Factors affecting microphytobenthic biomass, species composition and production in the Colne Estuary (UK). Aquatic Microbial Ecology, 27: 285-300.

Tomas, C.R. (1996). Identifying Marine Diatoms and Dinoflagellates. Academic Press, San Diego.

Trobajo, R., Mann D. G., Clavero, E., Evans, K.M., Vanormelingen, P. \& McGregor, R.C. (2010): The use of partial cox1, rbcL and LSU rDNA sequences for phylogenetics and species identification within the Nitzschia palea species complex (Bacillariophyceae), European Journal of Phycology, 45 (4): 413-425.

Rott, B.E., Pipp, E., \& Pfister, P. (2003). Diatom methods developed for river quality assessment in Austria and a cross-check against numerical trophic indication methods used in Europe. Algological Studies, 110: 91-115.

Underwood, G.J.C. (1994). Seasonal and spatial variation in epipelic diatom assemblages in the Severn Estuary. Diatom Research, 9: 451-472.

Underwood, G.J.C. (2010). Microphytobenthos and phytoplankton in the Severn estuary, UK: Present situation and possible consequences of a tidal energy barrage. Marine Pollution Bulletin, 61:83-91.

Underwood, G.J.C. \& Kromkamp, J. (1999). Primary production by phytoplankton and microphytobenthos in estuaries. Advances in Ecological Research, 29: 93-153.

Underwood, G.J.C., Philips, J. \& Saunders, K. (1998). Distribution of estuarine benthic diatom species along salinity and nutrient gradients. European Journal of Phycology, 33: 173-183.

Vilmi, A., Karjalainenc, S. M., Hellstenc, S. \& Heinoa, J. (2016). Bioassessment in a metacommunity context: Are diatom communities structured solely by species sorting? Ecological Indicators, 62: 86-94

Welker, C., Sdrigotti, E., Covelli, S. \& Faganeli, J. (2002). Microphytobenthos in the Gulf of Trieste (Northern Adriatic Sea): Relationship with Labile Sedimentary Organic Matter and Nutrients. Estuarine, Coastal and 
Shelf Science, 55: 259-273.

Wainright, S.C., Weinstein, M.P., Able, K.W. \& Currin, C. (2000). Relative importance of benthic microalgae, phytoplankton and the detritus of smooth cordgrass Spartina alterniflora and the common reed Phragmites australis to brackish-marsh food webs. Marine Ecology Progress Series, 200: 77-91.

Witkowski, A., Lange-Bertalot, H. \& Metzeltin, D. (2000). Diatom flora of marine coasts I. In Iconographia Diatomologica (Lange-Bertalot, H., editor), 7, 1-925. ARG Gantner Verlag KG, Ruggell.

Xu, H.L., Zhang, W., Jiang Y., Zhu M. \& Al-Resheid, K.A.S. (2012a). An approach to analyzing influence of enumeration time periods on detecting ecological features of microperiphyton communities for marine bioassessment. Ecological Indicators, 18: 50-57.

Xu, H.L., Zhang, W., Jiang Y., Zhu M. \& Al-Resheid, K.A.S. (2012b). Influence of sampling sufficiency on biodiversity analysis of microperiphyton communities for marine bioassessment. Environmental Science and Pollution Research, 19: 540-549.

Xu, H.L., Zhang, W., Jiang Y. \& Yang, E.J. (2014). Use of biofilm-dwelling ciliate communities to determine environmental quality status of coastal water. Science of the Total Environment, 470-471: 511-518. 
Table 1. Environmental factors (mean \pm SD) at three sampling sites $\mathrm{Re}, \mathrm{Ag}$ and Ay during the study period

\begin{tabular}{|c|c|c|c|c|c|c|}
\hline \multirow[t]{2}{*}{ Variables } & \multicolumn{3}{|l|}{ summer } & \multicolumn{3}{|l|}{ winter } \\
\hline & $\operatorname{Re}$ & $\mathrm{Ag}$ & Ay & $\operatorname{Re}$ & $\mathrm{Ag}$ & Ay \\
\hline $\mathrm{T}\left({ }^{\circ} \mathrm{C}\right)$ & $21.86 \pm 0.38$ & $29.82 \pm 0.50$ & $28.20 \pm 0.27$ & $9.34 \pm 0.09$ & $9.83 \pm 0.31$ & $11.03 \pm 1.31$ \\
\hline \multirow[t]{2}{*}{$\mathrm{R}\left(\mu \mathrm{mol} \mathrm{m} \mathrm{m}^{-2} \mathrm{~s}^{-1}\right)$} & 1533.32 & 1347.11 & 1613.18 & $222.60 \pm 62.68$ & $235.22 \pm 81.56$ & $97.07 \pm 11.63$ \\
\hline & \pm 359.86 & \pm 388.52 & \pm 23.83 & & & \\
\hline Pore water salinity & $46.00 \pm 2.53 a$ & $40.00 \pm 0.89 b$ & $47.67 \pm 0.58 a$ & $31.00 \pm 1.00 \mathrm{c}$ & $18.25 \pm 1.50 \mathrm{~d}$ & $10.00 \pm 0.00 \mathrm{e}$ \\
\hline D50 & $276.62 \pm 25.20 \mathrm{~b}$ & $8.85 \pm 0.27 d$ & $25.64 \pm 0.87 d$ & $394.27 \pm 114.57 a$ & $9.15 \pm 0.18 d$ & $120.21 \pm 1.41 \mathrm{c}$ \\
\hline$<63 \mu \mathrm{m}(\%)$ & $3.51 \pm 1.21 \mathrm{e}$ & $90.57 \pm 2.88 \mathrm{~b}$ & $78.92 \pm 1.09 c$ & $1.23 \pm 2.15 \mathrm{e}$ & $93.95 \pm 0.88 a$ & $37.33 \pm 0.61 d$ \\
\hline pH & $7.1 \pm 0.16 b$ & $7.0 \pm 0.15 b$ & $7.1 \pm 0.12 b$ & $7.10 \pm 0.11 b$ & $7.33 \pm 0.10 a$ & $7.47 \pm 0.23 a$ \\
\hline $\mathrm{OM}\left(\mathrm{gmL}^{-1}\right)$ & $1.49 \pm 0.08 c$ & $4.16 \pm 0.81 a$ & $4.36 \pm 0.18 a$ & $1.15 \pm 0.11 \mathrm{c}$ & $3.53 \pm 0.32 b$ & $1.80 \pm 0.06 c$ \\
\hline WC (\%) & $21.61 \pm 1.24 d$ & $69.93 \pm 6.79 a$ & $53.73 \pm 3.00 \mathrm{~b}$ & $21.58 \pm 1.68 \mathrm{~d}$ & $68.97 \pm 1.98 a$ & $27.89 \pm 0.49 c$ \\
\hline $\mathrm{NO}_{3}^{-}\left(\mu \mathrm{molL}^{-1}\right)$ & $3.70 \pm 4.30 c$ & $5.19 \pm 2.01 \mathrm{c}$ & $3.99 \pm 1.31 \mathrm{c}$ & $41.64 \pm 28.45 b$ & $73.33 \pm 73.07 \mathrm{~b}$ & $395.89 \pm 113.89 a$ \\
\hline $\mathrm{NO}_{2}^{-}\left(\mu \mathrm{molL}^{-1}\right)$ & $0.21 \pm 0.10 \mathrm{e}$ & $1.54 \pm 0.62 c$ & $0.61 \pm 0.26 c$ & $0.32 \pm 0.16 d$ & $4.31 \pm 2.80 \mathrm{~b}$ & $6.51 \pm 2.07 a$ \\
\hline $\mathrm{NH}_{4}^{+}\left(\mu \mathrm{molL}^{-1}\right)$ & $5.18 \pm 4.17 \mathrm{~b}$ & $70.56 \pm 61.79 a$ & $41.70 \pm 31.13 a b$ & $11.51 \pm 6.38 b$ & $21.93 \pm 9.81 \mathrm{ab}$ & $8.95 \pm 1.08 b$ \\
\hline $\mathrm{PO}_{4}{ }^{3+}\left(\mu \mathrm{moll}^{-1}\right)$ & $4.57 \pm 1.25 a$ & $10.60 \pm 9.72 a$ & $6.51 \pm 5.29 a$ & $3.42 \pm 0.35 a$ & $2.50 \pm 0.56 a$ & $1.37 \pm 0.14 a$ \\
\hline $\mathrm{Si}(\mathrm{OH})_{4}\left(\mu \mathrm{molL}^{-1}\right)$ & $5.83 \pm 3.80 c$ & $307.82 \pm 162.30 \mathrm{a}$ & $138.70 \pm 15.16 a b$ & $6.89 \pm 6.64 c$ & $69.80 \pm 28.75 b$ & $65.36 \pm 9.33 b$ \\
\hline $\mathrm{Zn}^{2+}\left(\mu \mathrm{g} \mathrm{g}^{-1}\right)$ & $10.58 \pm 1.93$ & $114.82 \pm 5.75$ & $75.62 \pm 3.70$ & $8.15 \pm 1.44$ & $113.70 \pm 3.23$ & $24.77 \pm 1.54$ \\
\hline
\end{tabular}

$\mathrm{R}:$ Irradiance; D50: diameter of 50\% of the sediment grains; $<63 \mu \mathrm{m}$ : percentage of sediment grain size $<63 \mu \mathrm{m}$; OM: organic matter content; WC: water content; Same letter denotes no significant difference between different sites or seasons, and different letter denotes significant difference by $<0.05$ as determinedby multiple comparisons in univariate analysis. 


\section{ACCEPTED MANUSCRIPT}

Table 2. Species number, diversity, evenness, richness, abundance and pigments of microphytonbenthos at three sampling sites during the study period, presented by mean $\pm \mathrm{SD}$, unit $\mathrm{mL}^{-1}$ means for fresh sediment.

\begin{tabular}{|c|c|c|c|c|c|c|c|c|c|}
\hline Season & Site & $\begin{array}{l}\text { Species } \\
\text { number }\end{array}$ & $\begin{array}{l}\text { Species diversity } \\
\text { (ShannonIndex) }\end{array}$ & $\begin{array}{l}\text { Species evenness } \\
\text { (Pielou Index) }\end{array}$ & $\begin{array}{l}\text { Species richness } \\
\text { (Margalef Index) }\end{array}$ & $\begin{array}{c}\text { Abundance } \\
\left(10^{5} \text { cells } \mathrm{mL}^{-1}\right)\end{array}$ & $\begin{array}{c}\text { Chl } a \\
\left(\mu \mathrm{g} \mathrm{mL}^{-1}\right)\end{array}$ & $\begin{array}{c}\text { Pheo-pigment } \\
\left(\text { ugmL }^{-1}\right)\end{array}$ & Chl $a /$ pheo \\
\hline \multirow{4}{*}{ summer } & $\operatorname{Re}$ & 35 & $2.25 \pm 0.14 a$ & $0.71 \pm 0.02 a$ & $3.73 \pm 0.45 b$ & $10.73 \pm 9.12 b$ & $38.79 \pm 2.78 a$ & $3.21 \pm 0.26 \mathrm{~d}$ & $12.14 \pm 1.12 b$ \\
\hline & $\mathrm{Ag}$ & 70 & $2.39 \pm 0.37 a$ & $0.70 \pm 0.05 a$ & $5.22 \pm 1.94 a b$ & $4.03 \pm 2.65 b c$ & $8.59 \pm 2.04 c$ & $11.77 \pm 3.29 b$ & $0.75 \pm 0.20 d$ \\
\hline & Ay & 58 & $2.59 \pm 0.14 a$ & $0.72 \pm 0.03 a$ & $6.12 \pm 0.68 a$ & $0.93 \pm 0.11 c$ & $29.06 \pm 1.78 b$ & $21.82 \pm 1.52 \mathrm{a}$ & $1.33 \pm 0.02 \mathrm{~cd}$ \\
\hline & $\operatorname{Re}$ & 30 & $2.01 \pm 0.17 a$ & $0.67 \pm 0.04 a$ & $3.14 \pm 0.40 \mathrm{~b}$ & $25.39 \pm 9.38 a$ & $38.71 \pm 12.14 a$ & $2.70 \pm 1.17 \mathrm{~d}$ & $16.09 \pm 6.59 a$ \\
\hline \multirow[t]{2}{*}{ winter } & $\mathrm{Ag}$ & 60 & $2.16 \pm 0.76 a$ & $0.63 \pm 0.17 a$ & $4.87 \pm 1.49 a b$ & $4.30 \pm 1.90 \mathrm{bc}$ & $11.57 \pm 4.66 c$ & $10.57 \pm 1.18 b$ & $1.08 \pm 0.38 d$ \\
\hline & Ay & 28 & $2.38 \pm 0.24 a$ & $0.77 \pm 0.08 a$ & $3.50 \pm 0.29 b$ & $6.30 \pm 1.39 b c$ & $41.76 \pm 3.58 a$ & $7.39 \pm 1.03 c$ & $5.69 \pm 0.51 d$ \\
\hline
\end{tabular}

* Same letter denotes no significant difference between different sites or seasons, and different letter denotes significant difference by $<0.05$ as determinedby multiple comparisons in univariate analysis. 


\section{Figure Captions}

Fig.1. Sampling sites in the coast of La Rochelle, France, Re in Re Island, Ag in Aiguillon Bay; Ay in Aytre Bay.

Fig.2. Grain size distribution in the studied sites. Grain size fractions expressed in percentage and consisted of mud $(<63 \mu \mathrm{m})$, very fine sand $(63-125 \mu \mathrm{m})$, fine sand $(125-250 \mu \mathrm{m})$, medium sand $(250-500 \mu \mathrm{m})$, and coarse sand (>500 $\mu \mathrm{m})$; A: summer, B: winter.

Fig.3 Taxonomic composition of microphytobenthic communities of individual samples collected from site $\operatorname{Re}(1-6), \mathrm{Ag}(7-12)$ and Ay (13-15), A: summer; B: winter. (The species with relative abundance above $5 \%$ are presented, with the remaining species grouped as 'others'. The relative abundance is presented as the percentage of the total cells couted).

Fig.4. Classification of samples based on species composition by nonmetric multidimensional scaling (nMDS) in CANOCO 5.0.

Fig.5. Detrended canonical correspondence analysis (DCCA) based on square-root transform of species abundance. The solid arrowheads and italic labels indicate the species: AchD: Achnantheiopsis delicatula; AmpH: Amphora hassiaca; AnoP: Anorthoneis pulex; AnoV: Anorthoneis vortex; $\mathrm{CocH}$ : Cocconeis hauniensis; CylC: Cylindrotheca closterium; DelM: Delphineis minutissima; EntC: Entomoneis corrugate; FalS: Fallacia scaldensis; GyrA: Gyrosigma acuminatum; GyrL: Gyrosigma cf. limosum; GyrF: Gyrosigma fasciola; NavA: Navicula abscondita; NavAl: Navicula aitchelbee; NavG: Navicula germanopolonica; NavGR: Navicula gregaria; NavP:Navicula perminuta; NavPH: Navicula phylleptosoma; NavS: Navicula sp.1; NitA: Nitzschia aequorea; NitP: Nitzschia panduriformis var.continua; PleA: Pleurosigma angulatum; SkeC: Skeletonema costatum; SurB: Surirella brebissonii; ThaV: Thalassiosira cf. visurgis; The lines with empty arrowhead and bold labels indicate the environmental factors: D50:diameter of 50\% of the sediment grains; OM: organic matter content; R: Irradiance; S: salinity; $\mathrm{pH} ; \mathrm{NO}^{2} \mathrm{NO}_{2}{ }^{-} ; \mathrm{NO}_{2}: \mathrm{NO}_{3}{ }^{-} ; \mathrm{NH}^{2}: \mathrm{NH}_{4}{ }^{+} ; \mathrm{PO}^{2}: \mathrm{PO}_{4}{ }^{3+}$; $\mathrm{Zn}: \mathrm{Zn}^{2+} ; \mathrm{Si}: \mathrm{Si}(\mathrm{OH})_{4}$. 
Highlights:

1. The variation in microphytobenthos community was spatio-temperal different

2. The microphytobenthos community closely relate to environmental factors

3. The community level index could assess the environmental quality status

4. Particular species can be bioindicator for specific environmental factor 